\title{
Integrating History of Economic Thought into Introductory Economics
}

\author{
C. Repapis ${ }^{1}$
}

Institute of Management Studies, Goldsmiths, University of London.

\begin{abstract}
:
In most universities in the UK history of economic thought, when it is taught, is taught either as a specialist or an optional module in the second and third year of the degree. This contribution argues in favour of introducing elements from the history of economic thought into the first year introductory economics module. The reasons why I see this to be an important change in developing curricula that teach economics through its history and evolution, are the following: 1) students learn from the beginning the context of economic ideas, instead of being introduced to economic theory in a de-contextualised way. This provides a framing effect for their whole undergraduate education in economics. 2) It allows history of economic thought to be seen in an integrated way as foundational of all knowledge in economic theory instead of another specialist topic, similar to other specialist topics like e.g. labour or financial economics, occasionally taught as options in years 2 and 3 in most degrees. This distinction is important, as specialist topics are seen as extensions of neoclassical theory into a specific domain of knowledge or application. History of economic thought, by its very subject matter, does not easily fit within such a framework. 3) It allows history to play a role in other modules, because it provides a unified framework for seeing knowledge in economics. 4) It allows the problimatisation of concepts that are still in dispute and discussion between economists, by presenting the historical context of modern conventions and conversations. 5) Finally, it allows the introduction of pluralism in economic curricula, as the differences between alternative paradigms or world views, can be presented from the beginning of the undergraduate programme of studies, allowing a broader and more diversified menu of optional and core module choices in years 2 and 3 of the degree.
\end{abstract}

\footnotetext{
${ }^{1}$ Correspondence can be addressed to Constantinos Repapis, Institute of Management Studies, Goldsmiths, University of London, New Cross, SE14 6NW. Email: c.repapis@gold.ac.uk
} 


\section{Introduction}

"A study in the history of opinion is a necessary preliminary to the emancipation of the mind."

Lord Keynes

Since the crisis of 2007 there has been a renewed interest in making the economic curriculum relevant with the events that are taking place at a global scale. This has provoked a variety of approaches from student movements to institutional responses. ${ }^{2}$ The plurality of approaches and responses has, in itself, been a substantial change to the prior situation when those responsible for undergraduate economic curricula, at least in the UK, have strived to increasing uniformity not only in the approach by which they teach economics, but also in the textbooks used. Therefore, some key textbooks, for example Mankiw's Macroeconomics, or Varian's Intermediate Microeconomics, had/have become the standard approach of these subjects in introductory and $2^{\text {nd }}$ year courses, imposing a uniformity between universities that reaches even the recesses of specific examples and other incidental detail.

In this chapter I will not attempt to review, or assess, these broader issues concerning the systematic curriculum changes attempted in some institutions, but will focus on broadening the debate by adding another possible way forward. This is trying to see the history of economic thought as another way to renew and refresh the economics curriculum, and bring it in closer contact with the social and economic reality that we live in. The previous sentence may appear to be founded on a contradiction. How could a field of study that appears both esoteric to the discipline and arcane, be a vehicle for making modern economics teaching rekindle its relation with the real world? The answer to this question can be summarised in the following way: By introducing context into the way we present both economic theory and the challenges of the modern economy.

The contextualisation of economic ideas is the foundational principle of the history of economic thought. In fact the very existence of this field of study arises from exactly an understanding on how economic ideas came about and what where the social/economic/political conditions that made these ideas both possible and popular. History of economic thought therefore includes as one of its central questions, the relation of ideas to the times and conditions that gave rise to them. This is one way to re-introduce the link between economic reality and theory that emanates from the very centre of the economic tradition and has remained dormant in recent years. This could supplement other efforts to re-invigorate this link; efforts that focus on inter-disciplinarity, or the introduction of

\footnotetext{
${ }^{2}$ There is an expanding literature on this topic, which cannot be surveyed here. A start may be (Sheehan, B.; J. Embery, and J. Morgan, 2015) or Morgan (2015) or Reardon, J. and M.A. Madi (2014), which review current mainstream institutional changes from a critical perspective. Also, this chapter does not review the CORE textbook advanced by a number of mainstream economists as an alternative textbook to existing introductory textbooks. It has been noted before (discussion in the plenary session of the European Society in the History of Economic Thought, XIX Annual Conference, Roma-Tre University, May 2015, and in Morgan, 2015, 19-22) that this textbook introduces history of economic thought in a limited way, as key economists, like David Ricardo or Karl Marx are given a very brief introduction in a textbox, and they are -at best- referred to briefly in other sections. It does not have a whole section in the history of economic thought, as such, nor does it present alternative economists as developing different systems of thought. Furthermore, it has been discussed extensively in the critical literature noted above. For these reasons I do not review this textbook here, but the reader can find further information and the textbook at: http://www.core-econ.org/
} 
new methods of analysis like case studies. These other ways to introduce context are not in competition with the introduction of a history of economic thought element in the curriculum, but would add strength and power to such an approach. It is my contention that the perspective of HET can act as an organising centre on these other approaches of introducing realism to the economic curricula, and in this short chapter I will explain how this can be done if we include topics from the history of ideas in a first year undergraduate module on introductory economics.

The chapter is structured as follows: Section II discusses the issues that arise with introductory economics in current curricula, and makes a general argument on the use of the history of economic thought in a first year introductory economics module. Section III reviews three past introductory economics 'anti-systemic' textbooks that had introduced HET in a substantial way. Section IV presents an alternative suggestion for a first year introductory economics module that uses the HET as its organising centre. Section $\mathrm{V}$ concludes.

\section{Introductory Economics- The Foundations}

Undergraduate university curricula usually have an introductory economics module that spans the first year of study. In some universities there is a distinction between single honours and joint honours degrees, where single honours degrees have modules in introductory microeconomics and introductory macroeconomics, with joined honours putting the two together in one course of introductory economics. It is interesting to note that these differences usually serve purely administrative considerations; some universities prefer modules with half credit running for one semester, others prefer full credit modules that run for a whole year. In single honour degrees there is also another augmentation, introductory micro/macro modules run for two semesters for full credit.

It is interesting to observe that this process, done rather routinely, immediately introduces the student to a division of the subject which is anything but straight forward. There is usually very little discussion or explanation why this separation is natural or useful from the perspective of understanding the economy, or even the discipline of economics. It hides the fact that the division is itself a point of controversy, and different economists would take alternative positions on what types of questions these two domains of knowledge should encompass. Finally, there is very little explanation why all foundational knowledge in economics must fall in either chapter heading- micro or macro. What happens with topics that cannot fall easily within it, like economic methodology, economic history or the history of economic thought? These are not parvenu fields that cannot fit on an established rubric, but are, fields that predate the rubric and can be seen as more foundational than the micro/macro divide itself. Any debate on the relation between microeconomic analysis and macroeconomic theory usually steps in a historical analysis of the evolution of the subject. An understanding of the evolution of microeconomics and macroeconomics, and the definitional or content controversies that they are party to it, is part of recreating the link between economic reality and the undergraduate rubric. 
It is therefore important to start any re-orientation of introductory economics by establishing the context of economic ideas, as a prequel to economic analysis rather than as an afterthought. Seen from this perspective the first few lectures should be focusing on presenting the intellectual and historical context of our social reality, and the economic and the social questions that are important. This start allows us to contextualise the most important question of economics, which is: What is economics? What is its domain of analysis?

Most introductory economics textbooks start from a definition of economics which is very close to Lionel's Robbins original formulation as expressed in his 1932 book. A standard quote for Robbins' book would be: "the science which studies human behaviour as a relationship between ends and scarce means which have alternative uses" (Robbins, 1935, 16). Occasionally the focus is not even so much on the problem of choice, but rather on the problem of scarcity itself, and choice is almost presented as a naturally occurring phenomenon whenever there is scarcity. Thus Krugman and Wells note the following "A resource is scarce when there isn't enough of the resource available to satisfy all the ways a society wants to use it" (Krugman and Wells, 2013, 6). This confusion on the fundamentals of what is the foundational question of economics is both puzzling and revealing. It is puzzling because one would have thought that since there is so much broad agreement in introductory textbooks on what economics is, there would be a precise and well expressed description of that definition, and an explanation of why this is the appropriate definition, possibly by investigating alternatives and showing their error. If we admit that there is no precise definition that is beyond dispute, one would have expected introductory economics textbooks to have in their opening pages a discussion of what different economists make of their discipline and its content. The fact that introductory economics textbooks do not follow either procedure is revealing of a broader educational principle which is more controversial. This is that students should not be presented by different viewpoints other than alternatives in vary stylised debates on specific issues. These alternatives are presented as contrasts that share the same basic understanding of the underlying real world problem, and their differences are only positional, and not fundamental or to do with the perception of economic reality as such. Thus, for example, students will be presented with the problem of inflation vs. unemployment in the macroeconomics parts of their textbook, and will learn that some people are more worried about unemployment than inflation, whereas others hold the opposite view. Viewpoints that do not fall on this axis are not presented-for example there are economists who question the use of unemployment as an aggregate index in itself, or others who do not find this tension to exist, or even others who see behind this construct no real analysis but instead a game of rhetorics that allows the persistence of higher unemployment for entirely different reasons to those offered in the debate.

Therefore, this way of introducing debate does not introduce students to the problem of incommensurability of different viewpoints. They are not presented with the problem of economists disagreeing with what the key issues are and, the inherent complexity of reality which does not have an easy relation to the symbolic models and assumptions of introductory textbooks. Furthermore, it offers students a disservice, as it makes them leave introductory economics modules with the implicit belief that all disputes in economics can be resolved by application to the same set of principles and methods, irrespective of the situation that they would have to deal with.

An appeal to the history of the subject could be a way to solve these issues without descending into incomprehension or a postmodernist view of the subject and its content. In fact, this would be not 
an introduction of new and untested principles, but instead an appeal to older ones that got lost in the process of change and standardization over the last 40 years. It is interesting to observe that a number of alternative introductory textbooks have made similar suggestions and have organised their material in this way in the past. In the next section I will concentrate on three examples which offers different ways of how such a re-integration can take place.

\section{Alternative Introductory Economics Textbooks- A Selective History.}

There have been a substantial number of anti-systemic textbooks from the end of the Second World War until today. This literature is too large to review here; instead my focus is the subset that reintroduced history of economic thought in a substantial way in their content. More specifically, I will focus on the following three introductory economics textbooks (in alphabetical order): ${ }^{3}$

- Cole, Cameron and Edwards, (1991 [1983]), Why Economists Disagree: The Political Economy of Economics, Burn Mill: Longmann

- Heilbroner and Thurow, (1981 [1968]), The Economic Problem, Sixth Edition, Prentice Hall: International Edition.

- Robinson and Eatwell, (1974 [1973]), An Introduction to Modern Economics, Revised Edition, London: McGraw Hill.

Heilbroner's textbook is the earliest of the three, as it was first published in 1968 by himself, and later with Lester Thurow in 1975 for the 4rth edition of the textbook. It was also commercially, the most successful of the three, as it run into six editions with the last one in 1981. By comparison, Robinson and Eatwell's textbook run for only two editions (the first one in 1973 and a revised in 1974). Also, Cole's, Cameron and Edward's textbook was published twice, first in 1983 and second in 1991. These three textbooks, seen together, provided alternatives that included more substantial material from the history of economic thought for about a quarter of a century. Their structure and presentation of the topics is not only interesting as an exploration in this periods' introductory economic textbooks, but can also guide us for the future integration of HET material in 1st year curricula as well.

That Heilbroner's book was something different to the introductory textbooks that were available at the time can be attested by contemporary book reviews. Groenewegen reviewed the book in The Economic Record and noted the following:

\footnotetext{
${ }^{3}$ This is not a complete list of all introductory textbooks that have a strong historical and HET element. For example, Hunt, Sherman, Nesiba, O'Hara, Wiens-Tuers. 2015 [2007], Economics: An introduction to traditional and progressive views, London: Routledge is not reviewed here. Hunt and Sherman before that wrote Economics; An Introduction to traditional and radical views (first edition 1972, sixth edition in 1990, New York Harper and Row. This edition is discussed in King and Millmow (2004)). The 2015 edition starts with two chapters on the "Economics of History and the History of Economics", before discussing macro and micro economics. This book is now at its 7nth edition and this -and its earlier version by two of the same writers- has been more of a success than the three textbooks reviewed in this section. I do not focus on this textbook as it is still available for academics to use and set a text for students taking introductory economics. Instead I focus on three textbooks that are not any more in print but had some attractive characteristics from the perspective of this chapter' thesis.
} 
"This is a newcomer to the already overcrowded field of introductory economics texts for the use of schools and first-year university courses, and since its competitors include such established texts as Samuelson, Reynolds, Bach, Lipsey, etc., the reviewer is faced with the task of seeing whether this new entrant has something original to contribute which distinguishes it to the all-too-familiar pattern of basic micro and macro economics, preceded by a brief introduction on scope and method and followed by international economics and current problems. As it is expected by a writer like Heilbronner, this path is not followed, and although basic micro and macro, are, of course, included, together with international and current problems, the introduction is highly original." (Groenewegen, 1969, 138)

Groenewegen goes on to explain that "Seven of the first eight chapters of the book (more than a quarter of the total volume) are devoted to economic history and the evolution of modern economic society..."(Groenewegen, 1969, 138). For Groenewegen this was not only a break with current practices in the textbooks available circa 1968, but, has been missing since the fifth edition of Marshall's Principles- the edition of Marshall's textbook that had economic history and history of economic thought in the beginning of the book rather than the appendixes that they occupied at the last (eighth) edition. He continues, "After Marshall, in any case, I know of no generally accepted textbook which has placed history in the foreground, until Heilbronner's book reached me." (Groenewegen, 1969, 139)

Although I will not trace the evolution of the book and its content from its first edition to the last, the following should be noted- by the last edition (1983) the introduction did not only focus on economic history, but also key thinkers of this period. Thus, chapter 2 was titled The Evolution of the Market System, and chapter 3 was titled The Great Economists. These two chapters work together, providing the strong historical framing effect that Groenewegen noted in his review. Thus, in Chapter 2 the following lines introduce the chapter: "There is one central idea that this chapter will present- a very simple but exceedingly important idea. It is that capitalism -our Western economic society- represents a dramatic change in the way that mankind has grappled with its economic problems" (Heilbroner and Thurow, 1981, 9). In Chapter 3 the introduction reads "The rise of one market system brought with it a great puzzle: to explain how such a system "worked"- what kept it together and in what direction it was headed. The name of this puzzle is economics" (Heilbroner and Thurow, 1981, 27). Therefore, economics is introduced in its proper historical place and in an engaging fashion- as the discipline that developed to explain the dramatic changes that took place from the industrial revolution until today. This creates a link between reality and abstract theory that to some degree frames the remainder of the book. By introducing in chapter 3 three key thinkers, Adam Smith, Karl Marx and John Maynard Keynes- the book by necessity introduces alternative world views of the economy, and this opens up spaces of competing interpretations of the social reality that would be missing from a more conventional text. This is even more forcefully pursued in the appendix of that chapter, which explores alternative paradigms in economics, and uses Thomas Kuhn's analysis to discuss historical changes from preclassical and classical economics to the marginalist and Keynesian revolutions. Nevertheless, by the sixth edition of Heilbroner's and Thurow's book this framing exercise is not utilised extensively in the more standard part of the textbook, and in some ways the innovative element of the first few chapters appears to be soon forgotten. Thus, while Karl Marx and Adam Smith are introduced in chapter 3, Marx is mentioned only twice and Smith only in a footnote reference in the next 600 pages. 
Another example, and a -famously- more radical assault to the standard textbook, was the joint venture between Joan Robinson and John Eatwell in the early 1970s. From the three textbooks discussed in this section this is the one that is more well known today among historians of the discipline. King and Millmow write the history of this textbook's publication and note in their introduction: "This textbook was designed to revolutionize the teaching of elementary economics and to displace the influence of mainstream texts like those of Paul Samuelson and Richard Lipsey. Its lack of success marked something of a turning point in the history of economics, since it symbolized the collapse of the radical attempt to challenge orthodox theory at the pedagogical level." (King and Millmow, 2003, 105) Furthermore, they note that "The history of economic thought occupy 16.4 percent of Robinson and Eatwell but only 3.2 percent of Samuelson" (King and Millmow, 2003,116). But this in itself is not the main difference between this book and Samuelson's, or other standard contemporary textbooks. The presentation and the arrangement of the material is substantially different, and this gave it the more radical thrust. King and Millmow undertake a content analysis between this textbook and the ninth edition of Samuelson's economics and find the following:

"He [Samuelson] begins with ten chapters of elementary theory, descriptive material, and institutional detail, and proceeds via the conventional macro and micro sections to distribution, the international economy, and a concluding section on "current economic problems." Introduction to Modern Economics starts with three chapters on the history of economic thought, followed immediately by the analytical core of the text, the eleven theoretical chapters of part 2. Here, as befits a product of the Cambridge school, the micro and macro are thoroughly integrated.... Thus the first two, apparently micro, chapters, titled "Land and Labour" and "Men and Machines," already contain material on growth, income distribution, and money. They are followed by two essentially macro chapters on effective demand and technical change; an (almost) pure micro chapter on "commodities and prices"; two mixed chapters on "rates of profits" and "incomes and demand"; a macro discussion of money and finance; chapter 9 on growth, which begins with the firm and moves first to the industry and then to the entire economy; a macro chapter on international issues; and a concluding chapter on socialist planning that again combines micro and macro problems. The only structural similarity with Samuelson comes in the third and final part of the book, which deals with the "modern economic problems" of capitalism, socialism, and the Third World." (King and Millmow, 2003, 116)

What this extensive quote shows is that the Robinson and Eatwell book (for all its shortcomings, and King and Milmow review these extensively), takes a bolder step in using the framing that history of economic thought provides in substantially re-organising the first year material on less established lines. Furthermore, the HET part is substantially more detailed than in the sixth edition of the Heilbroner and Thurow book. In Robinson's and Eatwell's book Chapter 1 is titled 'Before Adam Smith', Chapter 2 'Classical Political Economy', and Chapter 3 'The Neoclassical Era'. These chapters are to a very large degree purely concerned with the analytical elements of these schools- not so much with the historical conditions that gave them rise, other than noting the epoch as an aside. This is in marked contrast to Heilbroner and Thurow, that devoted equal weight to both history of 
economic thought and to the conditions of society during (and before) the industrial revolution- in the form of descriptive economic history. In contradistinction, Robinson and Eatwell use the HET section more extensively in the rest of their introductory textbook, and this is not only obvious by doing simple index accounting -Marx is mentioned in six pages outside the HET section, and this in a shorter book than Heilbroner and Thurow's- but by the tenure of their arguments which, at times, follow analytical arguments that emanate from classical or other schools of thought. ${ }^{4}$

This naturally leads us to the third book under discussion by Cole, Cameron and Edwards. This is by far the less well-known of these three textbooks and, it is also the most recent of them. It is also, I believe, the most idiosyncratic of the three and one which takes a step in a slightly different direction of organising the first year material on entirely new lines. Cole, Cameron and Edwards start with the postulate that economics' basic purpose is to explain value. Then they use the history of economic thought as a device to build three competing systems of theoretical analysis. They call the first "the subjective theory of value", the second "the cost of production theory of value" and the third "the abstract labour theory of value". They find then that these three schools differ markedly in a range of aspects, from methodological to policy questions. An example of this comparison can be seen in figure 1. What is stressed continuously and becomes abundantly clear to the reader is that these different schools of thought are incommensurable in how they analyse the economy. For example, the authors note in the criticism levelled against Marx that he has no theory of prices, "it is true, as we have stressed, that the derivation of prices is not the prime aim of the abstract labour theory, the main objective being the analysis of the dynamic of capitalism and of price formation by viewing capitalism at two levels - at the level of appearances (prices) and at the level of social relations (values)" (Cole, Cameron and Edwards, 1983, 228). This arraignment places modern micro theory in the first part of the book, that dealing with subjective theory of value, and distributes what would be considered as macro across different sections. But the important bottom line is that the micro/macro divide is not used at all, and indeed, what the book makes clear is that you can learn quite a lot of economics without even thinking that this is a useful partition of the material. This is not to say that the authors do not take sides- or have favourites among these three systems. But, what leanings there are in favour of one over the others can always be set within this frame of mind: it is simply the preference of the authors, and the reader can make his/her own mind. More importantly, they do they try to synthesise a common ground that cannot be found. This is a new experience for the reader, who learns that different theories in economics can illuminate different aspects of the economy, and these are derived from fundamentally different views of the social and economic reality. ${ }^{5}$ Here the link between theory and reality is multilevel. As Duhs notes in his book review "what Cole, Cameron and Edwards do very well, ..., is present an engaging account of the emerging evolution of economic thought in the context of the broadly based understanding of the emerging social, political, and philosophical issues of the day" (Duhs, 1985, 253). But this is only one aspect of the relation between theory and reality. More substantially, by introducing alternative incommensurable- viewpoints, the reader naturally is lead to be reflective about his/her own use of

\footnotetext{
${ }^{4}$ On this King and Millmow write "[Robinson and Eatwell] They had also integrated theory and history, analysis and institutions, giving their text a strong "comparative systems" orientation." (King and Millmow, 2003, 127)

${ }^{5}$ That this is a foundational aspect of this book can be seen not only from the title, but also from the following quote with which the book ends: "Our aim in this book has not been to stifle or preclude such theoretical debates but to provide a framework in which all the vital discussions of today can be understood and that many more people can actively participate in them. A greater understanding of one's own implied basic principles and those of opponents is crucial to such participation." (Cole, Cameron and Edwards, 1983, 289)
} 
the economic tools when confronting a real situation, and the deep political nature of economic questions. Whether this is a liberating or simply a confusing experience for the reader/student, is a deep issue that has clear educational ramifications. And even if we agree that it is in principle a liberating experience and, a necessary one if we want to produce economists who are citizens in democratic societies and are aware of the bias of their arguments, it may well hold dangers, both in asking too much from the $1^{\text {st }}$ year undergraduate student, and in creating a narrative that comes close to post-modernism- i.e. any viewpoint can be defended, and there are no wrong answers. This problem is one of the issues a more pluralist approach has always to deal with, and in this case it is solved by using lineages from the history of the subject. ${ }^{6}$

\section{An alternative suggestion for teaching introductory economics with HET}

Goldsmiths, University of London, started recently a new undergraduate degree in Economics (BA), to supplement its current undergraduate offering in Philosophy, Politics and Economics (BA), and Economics, Politics and Public Policy (BA). Furthermore, its new BA Economics degree introduces students both to interdisciplinary perspectives and to alternative theoretical paradigms within economics. These degrees necessitated a first year introductory economics module that could cater for a very diverse audience in background and motivation. Thus, the sequence of lectures and topics developed in introductory economics intends to present students with both the broader political contours of economic analysis, and lay the analytical foundations for those students that would continue with the more technical economics degree. Table 1 shows the topics that are covered in the 20 weekly two hour lectures divided in the two terms.

What this sequence of lecture shows is that the year is broadly divided into three sections. After an introductory week, students have five weeks of economic history/history of economic thought before going into eight weeks of microeconomic theory, and finally six weeks of macroeconomics. The first five week sequence is started with a lecture on the development of the modern economy, and intends to explain that many features of our social and economic reality are the outcome of the industrial revolution and the market economy that came to the scene in the 18nth century. This immediately provides historical context for the whole module, anchoring the analytical developments of economics within a specific period of human history. This counterpoint between developments in abstract theory and social/economic conditions is further strengthened in the next four weeks, where the following economists are discussed in sequence: Adam Smith, David Ricardo, Karl Marx and Alfred Marshall. These four weeks present economics through its 'system builders'theorists that strand the $19^{\text {th }}$ and early $20^{\text {th }}$ century and develop their own broad and comprehensive picture of how the economy works. Each lecture starts by presenting the person's

\footnotetext{
${ }^{6}$ The problem of post-modernism is dealt successfully in Cole, Cameron and Edward's book, by stressing that there are only three theories of value and describing these three in analytical detail. By creating complete systems, with exact historical lineages, the reader is aware of pluralism without going into an anything-goes narrative. But, this approach has weaknesses. That the construction of these histories leads to an occasionally controversial placements of theorists to fit the broader rubric is an aspect that can make some historians of economic thought (including me) uneasy. What I mean by this can be seen in figure 2 and the groupings of prominent economists there.
} 
lifetime, his times, and the methodology by which he tries to understand the economic and social reality before discussing some analytical arguments that emanate from his work. This focus on individual economists may appear as too biographical, but it has certain useful features. First, it introduces students to how economists try to create abstract arguments from observing the world around them- and few economists had been more successful in creating and projecting their abstractions to the profession as the four economists noted above. Second, it introduces students to alternative methodologies and approaches of doing abstract analysis in economics. Third, it introduces students to alternative schools of economic thought through their founders. This solves a number of problems. It gives plurality some structure, as students understand that the key thinkers have developed a whole system of analysis, and this system is both complex and has defined limits on what it intends -and can- explain. It also does not set a specific linear history of how these theorists relate to modern schools of thought, and the thinkers through the interim times that ascribe to this or that school, as attempted in Cole, Cameron and Edward's textbook.

This sequence of economists ends with Alfred Marshall that acts as a bridge to modern microeconomic analysis. Then students have five weeks that covers standard microeconomic topics, like consumer theory (axioms of preference, utility curves, etc.) and the theory of the firm (cost curves, perfect competition, monopoly, monopolistic competition). But even within these standard weeks the historical framework can be utilized in a variety of ways to give context to standard analysis. For example, at the end of three weeks of neoclassical choice, students in other universities are sometimes presented with some criticisms of this theory, and this is also the case here. The criticism presented is by Thorstein Veblen and his Theory of the Leisure Class. This work is not only an alternative understanding of consumption behaviour based on a class analysis of society, but also Veblen, a contemporary of Marshall, is seen as someone who analysed society on very different lines to Marshall's, and the contrast is pointed out. Veblen's work is presented not only as criticism of neoclassical individualistic rational choice theory, but as foundational to an alternative understanding of consumption behaviour, drawn on very different lines. This contrast is also utilised when presenting perfect competition- the student is introduced to Sraffa's (1926) critique before being presented to monopoly and monopolistic competition. ${ }^{7}$ The broader question here is whether market economies broadly tend towards competition or concentration- a question that links this technical discussion with the previous presentation of Marshall and Marx. Therefore, the point of these two contrasts is to discuss the overall utility of neoclassical theory in understanding social reality, and to briefly introduce alternative paradigms. Thus students can ponder questions of the following kind: Is consumption primarily determined by rational individual behaviour or more of a social phenomenon? Is most production taking place in an environment of perfect competition or of other market structures?

These questions are given their final articulation in the last three weeks of microeconomic analysis which is on partial and general equilibrium. The last topics presented are the two welfare theorems, and this closes a conceptual journey that started with Adam Smith and the presentation of the invisible hand and the virtues of exchange more than 10 weeks before. Thus students can see how economists have come to the final rigorous analytical articulation of the concept of the invisible hand and the assumptions that are needed to make it work. Microeconomics ends with a question: What do the welfare theorems tell us? Are they descriptive of the economy, or prescriptive of what

\footnotetext{
${ }^{7}$ This has been suggested by Avi Cohen. See Cohen (1996)
} 
we should aspire the economy to achieve? Or do they tell us something else? These questions have no definite answer, and the students are asked to think for themselves on the broad relation between central findings in economic theory and the economic and social reality of today.

The final part of the module deals with Macroeconomics. These final six weeks start with a discussion on the relation between microeconomics and macroeconomics, and the issues that arise in this relation. This sets the stage for the polyphony that usually takes place in macroeconomic discourse between different policy recommendations and the models that gave them rise. In this module, the first four weeks students are presented with introductory remarks on the usual array of topics: Aggregate indexes and national accounting, money and banking, growth and the real economy, AS/AD. The deference here in that each week students are also presented with a school of thought that is mostly associated with that topic. Thus, the first week sees a brief presentation of J.M. Keynes and the post-Keynesian school, the second a presentation of monetarism and the Austrians, the third an introduction to real business cycle, and the fourth an introduction to new Keynesian micro-foundations models. After these four weeks where students are presented both into the central topics of macroeconomics and on the main features of some macroeconomic schools of thought, they can start using these tools in important debates, which occupy the final two weeks of the introductory economics module. The first of these weeks is on the relation of inflation and unemployment, and students are presented with the variety of viewpoints that these schools have on this topic. The focus here is not to synthesise a common ground but instead to show that these topics are viewed very differently by these competing schools of macroeconomic thought. Finally the last week is titled 'Business Cycles or Economic Crises?' and this completes the intellectual journey that started in the beginning of the module with the question on what is this new type of society that has come to existence from the industrial revolution until today, how is it organised, and what are the issues of this new organisation. One central question in all this is whether this new system of consumption, production and exchange is prone to crises or, more generally what are we to make of these crises or cycles that seem to be a recurrent phenomenon. Here we have a topic of discussion that extends beyond macroeconomics and reaches as far back as the classical economists. Students can use the different narratives that have been built since the beginning of the module to articulate an opinion and also see the range of opinion on this topic. It is in this last week that this whole alternative scheme comes into a conclusion that utilises all the elements of the course, and sets old opinion on the same footing with contemporary and asks the student to discuss and debate these viewpoints. This shows that a history of economic thought section does not only add historical colour to an introductory economics module, but also opens up the range of opinion that the student gets exposed to, introducing an element of pluralism that emanates from the very core of the discipline.

\section{Conclusion}

The central questions that this chapter tried to answer are: why use topics from the history of economic thought in introductory economic modules and, how can this be done? The answers to these questions are not easy and depend on the motivation behind introducing topics from the history of the subject into the curriculum. A central question is whether one believes in a Whig 
history of economics, in which topics from the history of the subject are simply 'crowing out' material from the forefront of the discipline without adding anything. The other view is that the history of the subject can be used as a vehicle to introduce alternative viewpoints. Boulding in his classic paper (Boulding, 1971) makes the argument in favour of the second option by utilising the principle of the extended present. This principle argues that there is a period of time in which core understandings of a discipline are still evolving, and from which alternative viewpoints can be drawn. Boulding argues that books like The Wealth of Nations are part of the extended present, as they provide economists with new avenues of thought and research, which cannot be arrived at from contemporary models. This achieves a plurality of viewpoints that is unavailable to someone only studying the latest models. Thus Boulding argues "the Principle seems to me pretty clear that as long as intellectual evolutionary potential remains yet undeveloped in the early writers, the modern writers are a complement rather than a substitute" (Boulding, 1971, 231). This quote answers both the why and the how this can be done. The application of this principle was the main argument of the third chapter, where three introductory textbooks that implicitly utilised this principle where discussed, and the fourth chapter when an alternative introductory economics module was mapped out. These four viewpoints show that there can be many markedly different ways of introducing HET in the curriculum, and it would go against the very nature of the argument here, if it was proposed that the current monophony of introductory economics should be replaced by a new one that inserts HET in one specific way in introductory modules. If pluralism is a guiding principle, then it means not only the presentation of alternatives within a programme of studies or a module, but also alternatives between universities and in this case introductory economics courses. This could utilise better the different capacities and knowledge lecturers have, and provide prospective undergraduate students with a menu of options to choose from instead of one standardized product. That the creation of choice is welfare improving is a central result of neoclassical consumer theory for all products, and maybe it is time that the argument should be extended to the economics curricula as well. 


\section{$\underline{\text { References: }}$}

Boulding, K.E., 1971, "After Samuleson, Who Needs Adam Smith?" History of Political Economy, 3 (2), pp. 225-237.

Cohen, A.J., 1996, “Why Haven't Textbooks Resolved Sraffa's 1926 Complaints?” In N. Aslanbeigui and M.I. Naples, (ed.), Rethinking Economic Principles, Chicago: Irwin pp. 81-91.

Cole, K., J. Cameron and C. Edwards, 1991 [1983], Why Economists Disagree: The Political Economy of Economics, $2^{\text {nd }}$ edition, London: Longman

Duhs, L.A., 1985, "Book review of "Why Economists Disagree: The Political Economy of Economics"” Journal of Economic Issues, 19 (1), pp. 252-255

Groenewegen, P.D., 1969, "Book Review of 'The Economic Problem' by R.L. Heilbronner", The Economic Record, pp. 138-9.

Heilbroner, R.L. and L.C. Thurow, 1981 [1968], The Economic Problem, Sixth Edition, London: Prentice Hall International

Hunt, Sherman, Nesiba, O'Hara, Wiens-Tuers, 2015 [2007], Economics: An introduction to Traditional and Progressive Views, $7^{\text {th }}$ Edition, London: Routledge

King, J.E. and A. Millmow, 2003, "Death of a Revolutionary Textbook", History of Political Economy, 35:1, pp. 105-134

Krugman P. and R. Wells, 2013, Economics, $3^{\text {rd }}$ Edition, New York: Worth publishers.

Mankiw, G. 2015, Macroeconomics, $9^{\text {th }}$ Revised Edition, London: Palgrave Macmillan

Marshall, A., 1961, Principles of Economics, Ninth (Variorum) Edition, 2 volumes, London: Macmillan

Morgan, J., 2014, "Pluralism, heterodoxy, and the prospects for a new Economics Curriculum: Assessing the potential of INET, What's the Use of Economics, and the CORE project", Association for Heterodox Economics, found in:

http://www.hetecon.net/documents/The_prospects_for_a_new_economic_curriculum.pdf

Reardon, J. and M.A. Madi (2014), "Introduction" in M.A. Madi and J. Reardon (eds), The Economics Curriculum: Towards a Radical Reformulation, Milton Keynes: World Economics Association, pp. 312.

Robbins, L., 1935, An Essay on the Nature and Significance of Economic Science, Second edition, London: Macmillan and Co.

Robinson, J. and J. Eatwell, 1973 [1974], An Introduction to Modern Economics, Revised Edition, London: McGraw Hill

Samuelson, P.A., 1973, Economics, $9^{\text {th }}$ edition, New York: McGraw-Hill 
Sheehan, B.; J. Embery, and J. Morgan, 2015, "Give The Something to Think About, Don't Tell Them What to Think: A Constructive Heterodox Alternative to the CORE Project." The Journal of Australian Political Economy, 75, pp. 211-232.

Sraffa, P., 1926, "The Laws of Returns under Competitive Conditions", Economic Journal, 36 (4), pp. 535-50

Varian, H., 2014, Intermediate Microeconomics: A Modern Approach, 9nth International Student Edition, W. W. Norton \& Company.

Veblen, T.B., 1957, The Theory of the Leisure Class, London: Allen and Unwin. 
Table 1 - Introductory Economics (30 credits) at Goldsmiths, University of London

\section{Term (Semester) 1}

Week 1- What is Economics?

Students are introduced to alternative perspectives on what is economics from mainstream and heterodox texts.

\section{2- What is a Market Economy?}

Students are presented to a brief economic history of western Europe, and the importance of the industrial revolution. It is indicated that economics, as a discipline, developed to explain these unprecedented social and economic changes.

\section{3- Adam Smith}

Introduction to key aspects of the Wealth of Nations, especially the division of labour, the extent of the market and the human inclination to exchange.

\section{4- David Ricardo}

Introduction to the corn model and the theory of comparative advantage. Students learn about the three classes in Ricardo- Landowners, Workers and Capitalists.

\section{5- Karl Marx}

Introduction to key aspects of Marx's thought, including his theory of value, stages of socioeconomic development, and the contradictions of capitalism.

\section{6- Alfred Marshall}

Principles of Economics, the small scale producer responding to market changes. Introduction to the following concepts: normative/positive, opportunity cost, Pareto principle, supply/ demand.

\section{7- Consumer Theory I}

Marshall was the link with modern micro analysis, and this week we cover: preference theory,

budget constraints, graphical construction of utility curves.

\section{8- Consumer Theory II}

Introduced to income and substitution effects, and then to neoclassical theory (labour-leisure decision) of providing labour to the competitive market.

\section{9- Consumer Theory III}

First hour: students are introduced to intertemporal neoclassical consumer choice.

Second hour: Criticism of neoclassical consumer choice through the work of Thorstein Veblen's work (Esp. The Theory of the Leisure Class).

\section{0- Producer's Problem- Costs of Firms}

Introduced to cost curves, and the maximisation problem of a small competitive firm. The concepts of Returns to Scale and Minimum Efficient Scale are presented and critically discussed.

\section{Term (Semester) 2}

1- Producer's Problem- Competitive Firms

raffa's 1926 article and departures from perfect competition that do not involve strategic interaction: Monopoly, Monopolistic Competition.

2- Supply/Demand and Partial Equilibrium Welfare Analysis

Students are introduced to the following: consumer and producer surplus, government intervention and welfare analysis: Taxation, quantity restrictions, price floor-ceilings. Definition of an ideal market.

3- General Equilibrium I

Introduction to pure exchange between two individuals (Edgeworth box). Difference between partial/general equilibrium. 1st Welfare Theorem.

4- General Equilibrium II

First hour: $2^{\text {nd }}$ WT. What is the meaning of the welfare theorems? Descriptive, prescriptive or something else? Second hour: The relation between micro and macro. 5- The Modern Macroeconomy

Topics covered: Introduction, national accounting macroeconomic aggregates. Presentation of School of Thought: J.M. Keynes and Post-Keynesian theory.

\section{- Money and Banking}

Topics: what is money, quantity theory of money, demand for money. Presentation of two Schools of Thought: 1) Monetarism. 2) Austrians. 7- Growth and the Real Economy

opics: Solow growth model, rational expectations.

Presentation of Schools of thought: Real Business Cycles.

\section{8- Aggregate Fluctuations- AS/AD}

Topic: Short-run vs. Long run AS-AD.

Presentation of School of thought: New-Keynesian micro-foundation models.

9- Macroeconomic Debate I: Inflation/Unemployment

Topics: Inflation or Unemployment? A trade-off?

Views from the various schools of thought: Different framing of the problem depending on the school of macroeconomic thought.

10- Macroeconomic Debate II: Business Cycles/Economic Crises

Topics: Business Cycles or Economic Crises? Are they the same thing? An exploration of the problem of crises from Ricardo and Marx to RBC. 
Figure 1: Three Theories of Value and their differences in Cole, Cameron and Edwards (1983)

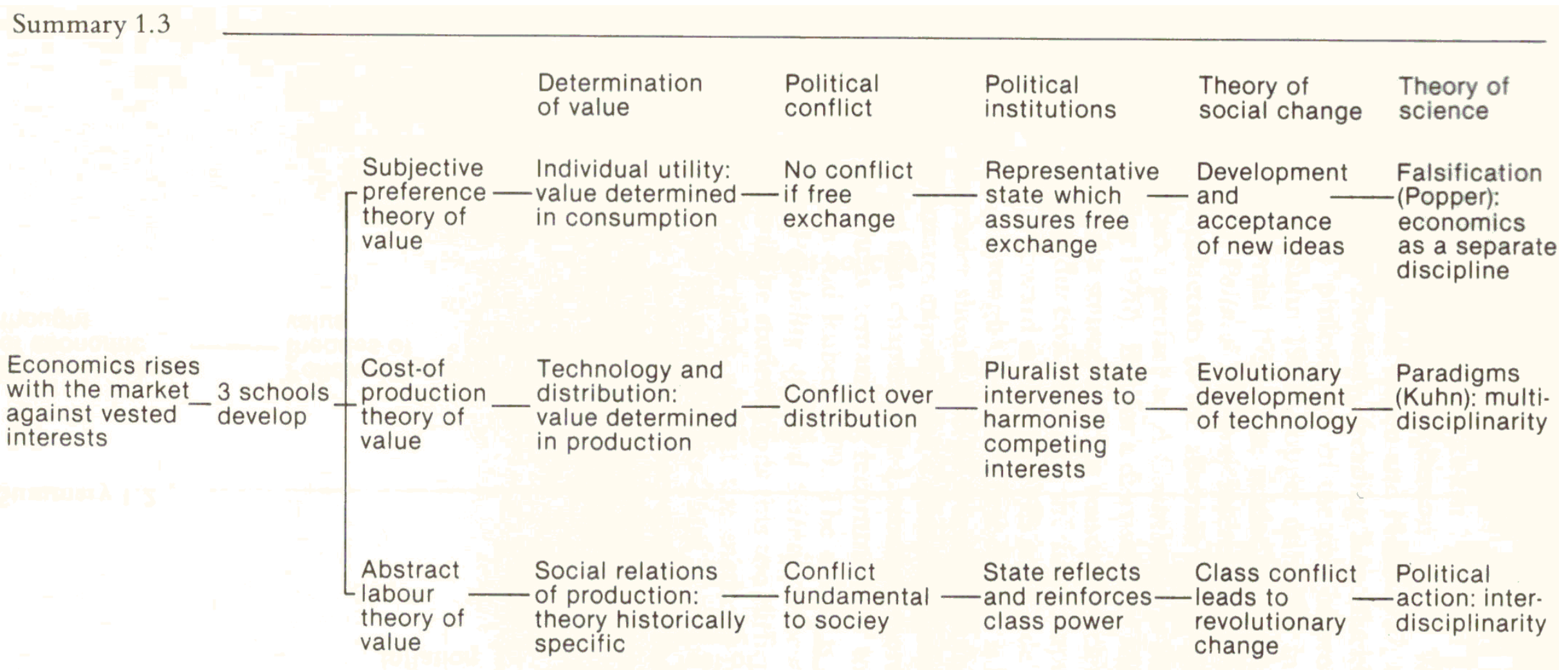

Source: Cole, Cameron and Edwards, 1983, Why Economists Disagree: The Political Economy of Economics, London: Longman page 20 
Figure 2: The Historical Development of the Three Theories of Value in Cole, Cameron and Edwards (1983)

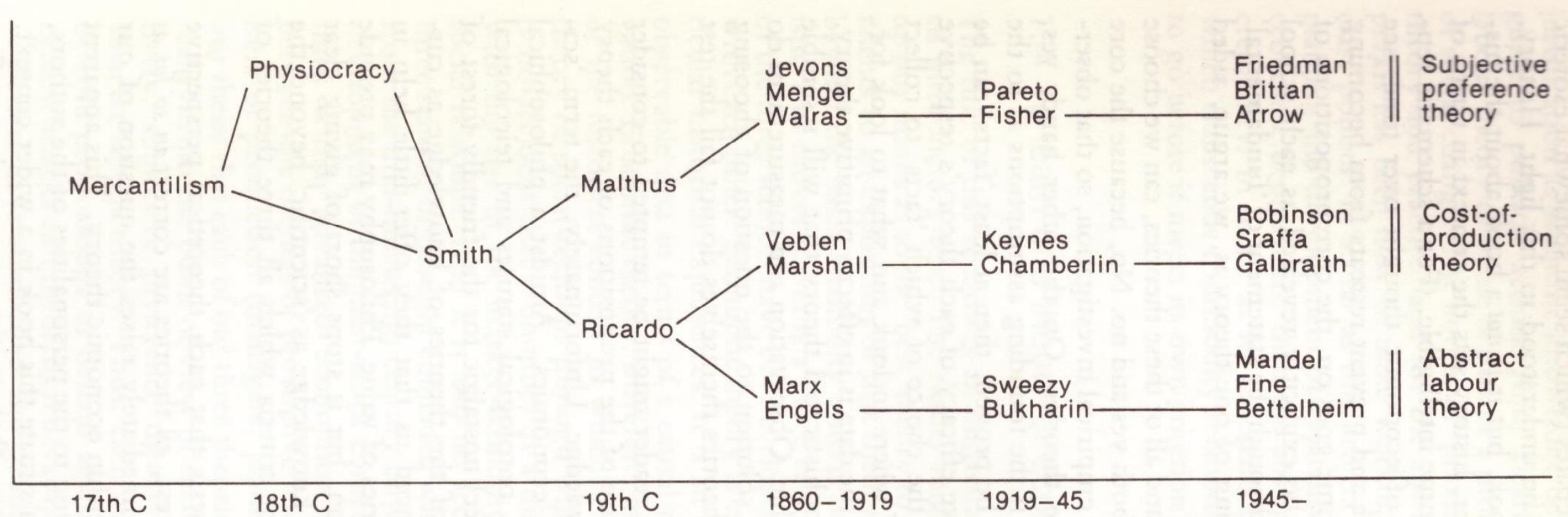

Fig. 1.1. The historical development of economic theory

Source: Cole, Cameron and Edwards, 1983, Why Economists Disagree: The Political Economy of Economics, London: Longman page 16 